\title{
FIRM OPENNESS AND MANAGERIAL INNOVATION: REBALANCING DELIBERATE ACTIONS AND INSTITUTIONAL PRESSURES
}

\author{
Rachel BOCQUET \\ Institut de recherche en gestion et économie, Université Savoie Mont Blanc \\ rachel.bocquet@univ-savoie.fr \\ Sandra DUBOULOZ \\ Institut de recherche en gestion et économie, Université Savoie Mont Blanc \\ sandra.dubouloz@univ-savoie.fr
}

\begin{abstract}
The two main perspectives regarding the drivers of managerial innovation (MI) - institutional and rational - are often presented as contrasts in previous literature. This article seeks to bridge the two perspectives in an effort to analyze the external antecedents of MI in an open innovation framework. Using the French Organizational Change and Computerization survey, this analysis reveals that $\mathrm{MI}$ is influenced not only by active external search strategies but also by coercive pressures and a quest for legitimacy. The results also indicate a substitution effect between external search activity and absorptive capacity in relation to MI. That is, openness is beneficial for managerial innovation in manufacturing firms but internal obstacles still dominate.
\end{abstract}

Keywords: Managerial innovation, Open innovation, Rational approach, Institutional theory, Manufacturing firms.

JEL: O31, L60

\section{INTRODUCTION}

Open innovation, which puts the emphasis on both external and internal knowledge sources, has rarely been related to managerial innovation (MI) (Damanpour et al., 2018; Huang, Rice, 2012). Part of the explanation lies in the fact that much research on open innovation has focused on technological innovations, especially product innovations in high-R\&D settings (Loilier, Tellier, 2011). Yet systematic reviews show the dominance of studies on technological innovations, and point out the lack of research on non-technological innovations in relation to open innovation (Černe et al., 2016; Crossan, Apaydin, 2010; Keupp et al., 2011).

The scarcity of research on the relationship between open innovation and MI can find another explanation in the MI literature. Most studies on MI focus on internal antecedents (Damanpour, Aravind, 2012) and neglect the influence of external factors. The few studies that discuss the effect of firms' openness in relation to MI tend to adopt two distinct perspectives - rational or institutional - without any synthesis (Birkinshaw, et al.,2008), knowing that open innovation is usually based on a rational perspective, neglecting institutional forces (Tsinopoulos et al., 2018).

In this study, we seek to provide a better understanding of the relationship between firm openness and $\mathrm{MI}$ adoption by combining the rational and the institutional perspectives. 
The rational perspective is built on the premise that $\mathrm{MI}$ adoption is driven by rational choice (Damanpour, Aravind, 2012). It assumes that new managerial practices are deliberately introduced by key individuals within organizations to improve performance (Vaccaro et al., 2012). However, some research also shows that the benefits of openness can be subject to decreasing returns for technological innovations (Laursen, Salter, 2006), depending on the firm's capacity to assimilate, transform, and exploit external knowledge (Cohen, Levinthal, 1990; Lichtenthaler, 2011; Zahra, George, 2002). Other studies confirm the crucial role of dimensions other than external knowledge sources, such as investments in absorptive capacity (Chiaroni et al., 2010; Clausen, 2013; Flor et al., 2018; Huang, Rice, 2012; Lichtenthaler, Lichtenthaler, 2009; Lin et al., 2016). With a few exceptions (Damanpour, et al., 2018; Huang, Rice, 2012; Mazars-Chapelon et al., 2018; Mol, Birkinshaw, 2014), these studies focus on the development of new products, largely ignoring the introduction of new processes, in particular non-technological ones (Tsinopoulos, et al., 2018). Moreover, the impact of these dimensions and their potential relationship with firms' innovation remain ambiguous, though, in particular with regard to MI. Some authors assert that firms with a high level of absorptive capacity benefit more from external knowledge (Escribano, 2009; Lin, et al., 2016), whereas others demonstrate a substitution effect between absorptive capacity and openness (Laursen, Salter, 2006).

By contrast, the institutional perspective does not consider MI adoption as a goal-oriented decision. This perspective indicates that the introduction of new managerial practices is a fador fashion-driven process (Abrahamson, 1991) that reaffirms control over firms (DiMaggio, Powell, 1983). In this forced-selection view, multiple organizations (e.g. clients, suppliers) may have sufficient power to dictate what MI should diffuse across organizations (DiMaggio, Powell, 1983). It has also been shown that pressures to imitate competitors' adoption decisions are salient (Abrahamson, 1996). That is, in such a perspective, firms can adopt MI in response to bandwagon pressures, created by the sheer number of organizations that already adopted them (Abrahamson, 1991).

This article aims to disentangle the effects of deliberate actions versus external pressures to investigate the 'true' antecedents of openness in relation to MI adoption. We thus examine whether, and to what extent, MI is the result of a deliberate knowledge search, of external pressures, or both?

The empirical analysis we undertake to answer these questions relies on a unique French data set, Organizational Change and Computerization (Changement Organisationnel et Informatisation; COI), for 2003-2006. In our cross-sectional study, we use a representative sample of more than 4,300 manufacturing firms. The COI database provides detailed information about the MI that firms adopt, their external knowledge sources, their absorptive capacity, and their institutional environment.

The results show that MI is influenced not only by external search strategies but also by external pressures. Thus openness, a concept that has mainly applied to technological innovation, is also meaningful for manufacturing firms that seek to adopt MI. Up to a certain threshold; the more open the firm, the more it adopts MI. The results also suggest a complementary nature of absorptive capacity and open innovation search strategies on MI adoption.

With these findings, we make three main contributions. First, this study broadens research into the antecedents of a largely neglected type of innovation (Damanpour, Aravind, 2012; Vaccaro, et al., 2012; Volberda, et al., 2013). We not only provide a more nuanced characterization of the external antecedents of MI but also reconsider the conclusions of studies that tend to privilege an open innovation perspective without considering institutional pressures. Second, this study provides a more comprehensive understanding of open innovation by including two main perspectives - rational and institutional - (Randhawa et al., Wilden, 2016) and offers a new path for research, in that it shows that open innovation can be extended and apply to new contexts and non-technological innovations (Gassmann et al., 2010; Huizingh, 2011). Third, 
following calls for more research (Lane et al., 2006), we propose an operationalization of absorptive capacity in a non-exclusive R\&D context, using metrics that capture the different dimensions of the absorptive capacity process (Dubouloz, Bocquet, 2013). From a managerial perspective, a better understanding of the drivers of MI offers useful guidance, in support of firms' innovation and growth.

In the next section, we describe the theoretical bases of our empirical analysis. We then present the data and empirical models. After detailing our results, we conclude with a discussion of the main theoretical and managerial implications of our findings and propose several paths for further research.

\section{THEORETICAL BACKGROUND}

\section{Open innovation and managerial innovation adoption: an understudied relationship}

MI is a non-technological process innovation (Edquist, et al., 2001; Evan, 1966), defined as the introduction of management practices, process, structure or technique new to the firm and intended to enhance firm performance (Birkinshaw, et al., 2008; Mol, Birkinshaw, 2009; Volberda, et al., 2013). Unlike market-driven products and service innovations, MI has an internal focus and aims to increase the efficiency and effectiveness of the organizational process (Boer, During, 2001; Utterback, Abernathy, 1975). For this study, we focus on MI adoption by firms, whether the innovation is generated internally, acquired from another pioneering organization, or imitated (Damanpour, Aravind, 2012). Adoption then involves the decision by which an organization (or organizational unit) selects, adapts and implements new organizational and managerial practices, then assimilates them into its operations and activities. MI adoption is a complex process, for which new knowledge has a crucial role. It results from the combination of existing and new knowledge. External actors, as important knowledge sources, are pivotal to MI adoption success (Damanpour, et al., 2018). In that respect, openness should favour MI adoption.

However, as noted by Mol and Birkinshaw (2014), there is very little research that applies an open innovation perspective to MI. Among these rare studies (Laursen, Salter, 2006; MazarsChapelon, et al., 2018; Mol, Birkinshaw, 2009, 2014), are those that mainly focus on the generation (new to the state of the art) of MI and they do not always take into account internal involvement and capabilities (Damanpour, et al., 2018). To the best of our knowledge, there is only one study on the relationship between open innovation and MI adoption in the context of public organizations (Damanpour, et al., 2018).

\section{The open innovation paradigm: looking at rational and institutional perspectives}

Two views continue to prevail in the open innovation literature: a technologic-centred view or a rational-view of open innovation, which both consider that opening the innovation process is invariably a rational or efficient choice (Bogers, et al., 2017 ; Damanpour, et al., 2018). Besides, another perspective, the institutional one, based on theoretical explanations from institutional, network, and behavioural contagion theories argues that firms introduce MI for social and institutional reasons rather than purely rational ones (Abrahamson, 1991 ; Staw, Epstein, 2000).However, institutional forces are still neglected (Tsinopoulos, et al., 2018) as emphasized by very recent study claims that open innovation has to be analysed considering institutional arguments (Radnejad et al., 2017). In line with the non-technological innovation literature, we 
consider that diverse rationales, including rational and socially conditioned responses, have to be taken into account as they can significantly influence MI adoption (Daniel et al., 2012 ; Huang, Rice, 2012 ; Radnejad, et al., 2017 ; Tsinopoulos, et al., 2018).Then, as recommended by Damanpour, et al. (2018), it seems crucial to confront rational and institutional perspectives to provide a better understanding of the relationship between firm openness and MI adoption.

\section{The rational perspective: deliberate actions on managerial innovation adoption}

Using the rational perspective, an open innovation framework can provide useful complementary elements for understanding the MI adoption through the voluntary search for external knowledge and the development of internal capacities to deal with external knowledge.

\section{Deliberate search for external knowledge sources}

Open innovation refers to voluntary exchanges of knowledge, as tools to enhance internal innovation and its potential uses (Chesbrough, 2006). Opening firm boundaries becomes a source of sustainable competitive advantage and a 'powerful generative mechanism to stimulate innovation' (Chesbrough, 2012, p. 21). In turn, open innovation comprises two main dimensions: (1) outside-in or inbound, which enables firms to establish relationships with external actors to acquire or explore knowledge, and (2) inside-out or outbound, such that firms establish relationships with external actors to exploit or sell their knowledge (Chesbrough, 2012; Chiaroni et al., 2010; Grassmann, Enkel, 2006). We focus here on inbound open innovation.

Laursen and Salter (2006) introduce two variables to capture firms' openness: search breadth, or the number of external sources used by firms, and search depth, defined as 'the extent to which firms draw intensively from different search sources' (p. 140). Searching voluntary both widely and deeply across a vast range of external knowledge sources provides ideas and resources that can be conducive to product innovation (Laursen, Salter, 2006). Escribano, et al. (2009) and Tsinopoulos, et al. (2018) confirm that firms that enjoy more external knowledge flows are more technologically (product and process) innovative. Similarly, Lazzarotti and Manzini (2009) argue that the number and diversity of firm partners (e.g., universities, suppliers, consumers, competitors, consultants, other enterprises in the same group) determine the level of innovation openness. However, there also may be "tipping points", after which openness to external knowledge sources leads to decreasing innovation performance (Huang, Rice, 2012 ; Laursen, Salter, 2006).

Open innovation studies mainly focus on product innovation and R\&D activities though, despite evidence that open innovation is increasingly common for process innovation (Reichstein, Salter 2006 ; Robertson et al., 2012 ; Utterback, Abernathy, 1975). For example, Birkinshaw, et al. (2008) assume that MI "emerge in vitro" (p. 840), or at least in non-isolated contexts, resulting from interactive processes with internal and external actors. With data from the UK Community Innovation Survey (CIS3), Birkinshaw and Mol (2006) find that firms adopt new management practices as a consequence of external search for new knowledge, not only when ideas are offered by market participants (customers, suppliers, competitors, consultants) but also when they use internal and professional sources (professional associations, industry bodies). Using the German CIS4 survey, Ganter and Hecker (2013) validate the crucial role of external sources of knowledge for MI. Another study of Australian business units shows that inter-organizational collaborations foster process innovations, including technological and MI (Huang, Rice, 2012). Despite these advances, we still do not know whether too many external knowledge sources can hinder the adoption of MI. That's why, we propose: 
$\boldsymbol{H} 1$ : In an open innovation strategy, deliberate search for external knowledge sources is curvilinearly related to the intensity of MI adoption.

\section{Absorptive capacity}

Beyond firms' external relationships, open innovation rests on their internal integration mechanisms and investments in absorptive capacity (Huang, Rice, 2012 ; Lichtenthaler, Lichtenthaler, 2009). Absorptive capability allows a firm to 'recognize the value of new, external information, assimilate it, and apply it' (Cohen, Levinthal, 1990, p. 128). As Chiaroni, et al. (2010) argue, open innovation involves not only inter-organizational networks but also the implementation of voluntary practices to develop absorptive capacity, such as organizational structures, evaluation processes and knowledge management systems. Among a large sample of Australian firms, Huang and Rice (2012) confirm that inter-organizational collaborations, evaluation processes and organizational structures co-vary positively and significantly with product and service innovation performance. Clausen (2013) examines the link between absorptive capacity and the intensity of innovation cooperation and finds that some absorptive capacity dimensions (internal R\&D, human capital, and training) are positively associated with search breadth. Other studies that use single-dimensional measures of absorptive capacity confirm that R\&D expenditures (Battisti, Stoneman, 2010 ; Polder et al., 2010) or prior knowledge (Wischnevsky et al., 2011) could be important drivers of MI.

However, the relationship between absorptive capacity and innovation is relatively less well documented for non-technological innovations (Kostopoulos et al., 2011) and results are less clear-cut. Indeed, Huang and Rice (2012) show that internal R\&D does not affect the adoption of managerial processes, while human capital does. In general though, we predict a positive effect of absorptive capacity on MI.

H2: In an open innovation strategy, firms' absorptive capacity is positively associated with the intensity of MI adoption.

\section{Interaction between external knowledge sources and absorptive capacity}

Access to external information can drive innovation success, but the presence of valuable external sources of knowledge does not imply that the flow of external new ideas and knowledge into firms is an automatic or easy process (Clausen, 2013). Internal mechanisms are necessary (Chiaroni, et al., 2010 ; Huang, Rice, 2012), if not indispensable (Kostopoulos et al., 2011), to foster recognition of the value, assimilation and application of external knowledge (Cohen, Levinthal, 1990). That is, external knowledge is 'not freely and effortlessly absorbed by the firm' (Fabrizio, 2009, p. 257). Escribano, et al. (2009) highlight that firm with higher levels of absorptive capacity benefits more from external knowledge flows. They also find complementarity between absorptive capacity and external knowledge sources, which enhances firms' technological innovation performance. Similarly, Flor, et al. (2018) show a positive effect on the relationship between external search and radical technological innovations. Kostopoulos, et al. (2011) also show that absorptive capacity mediates the relationship between external knowledge inflows and technological innovation, though they find no significant direct effect of external knowledge.

In contrast, Laursen and Salter (2006) find a substitution effect between openness and absorptive capacity (i.e. internal R\&D). External knowledge thus does not enter the firm freely, and knowledge searches can be time consuming, expensive, and laborious. Developing high absorptive capacity also is costly (Clausen, 2013), so firms, especially small ones, might lack the necessary resources to develop both external and internal new knowledge routines. Accordingly, we predict a substitutive effect: 
H3: In an open innovation strategy, deliberate search for external knowledge sources coupled with firms' absorptive capacity are negatively associated with the intensity of MI adoption.

\section{The institutional perspective: External pressures on managerial innovation adoption}

External actors, as important knowledge sources, are pivotal to innovation success (Rosenberg, 1982). However, openness is not always the result of deliberate actions. Institutional theory highlights the role of social concerns and offers significant insights regarding the importance of pressures from external actors, the motivation to achieve legitimacy or mimetism to explain the adoption of certain practices or MI, as opposed to profit maximization (Birkinshaw, et al., 2008 ; Radnejad, et al., 2017 ; Tsinopoulos, et al., 2018). For instance, from a multiple case study, Radnejad, et al. (2017)show that institutional forces, such as social and environmental pressures, were the primary drivers for adopting open innovation in the Canadian oil industry. Thus, the decision to adopt new managerial practices could do more with the institutional environment in which the firm is situated than with rational organizational criteria (DiMaggio, Powell, 1983).

Some scholars attempt to identify the mechanisms that trigger the external influences that drive MI adoption, beyond the technical efficiency of the innovation ${ }^{1}$. According to the force selection perspective (Abrahamson, 1991) or coercive isomorphism (DiMaggio, Powell, 1983), external partners exert pressures to urge firms to adopt new managerial practices. DiMaggio and Powell (1983) conclude that a position of dependence on clients or suppliers is a good predictor of coercive isomorphic. For instance, customers are looking for evidence of the existence of management systems and control mechanisms as a way of ensuring that the potential supplier is able to consistently provide the products and services they have promised (Anderson et al.,1999 ; Matias, Coelho, 2002). With case studies of French manufacturing firms that have adopted lean practices, Dubouloz (2012) finds that key clients can urge their subcontractors to adopt new managerial practices by setting high quality standards and delivery requirements, such that they present new solutions as 'best practices', previously tested in other firms. Suppliers also significantly influence the probability of MI adoption by applying persuasive marketing tactics (Frambach, Schillewaert, 2002) or control over scare resources (Pfeffer, Salancik, 1978).

However, external pressures do not always derive from coercive authority. According to the fad and fashion perspective (Abrahamson, 1991) and mimetic processes (DiMaggio, Powell, 1983), some firms imitate actions or managerial practices adopted by other users that appear better able to cope with economic difficulties and market constraints. Firms that obtain knowledge from prior or current adopters enjoy reduced uncertainty and informational asymmetries related to MI and its effects (DiMaggio, Powell, 1983 ; Teece, 1980). Moreover, when the motivation is the desire to be seen as legitimate, the aim is not to adopt a MI that achieves an immediate cost saving or improvement of internal process, but to find a way of doing things which meets standards of best practice (Sherer, Lee, 2002).These arguments from an institutional perspective suggest:

H4: In an open innovation strategy, coercive pressures are positively associated with the intensity of MI adoption.

H5: In an open innovation strategy, mimetic pressures are positively associated with the intensity of MI adoption.

\footnotetext{
${ }^{1}$ The institutional theory focuses on three mechanisms: mimetic, normative and coercive isomorphism (DiMaggio and Powell, 1983). Given the theoretical and empirical difficulties of differentiating the effects of mimetic and normative pressures, we follow Chen et al. (2011) focusing on mimetic and coercive mimetic and normative pressures.
} 
H6: In an open innovation strategy, the quest of legitimacy is positively associated with the intensity of MI adoption.

\section{DATA AND METHODS}

\section{Sample}

The French Organizational Change and Computerization (COI) survey is conducted by researchers and statisticians from INSEE (National Institute for Statistics and Economic Studies) and DARES (Ministry of Labor). The 2006 version provides a rich source of information about new lean management practices adopted by firms since 2003; the respondent firms also indicated the external and internal conditions in which they decided to adopt lean practices. The survey included 14508 firms with more than nine employees, across all sectors, though for our cross-sectional analysis, we restrict the sample to 4319 manufacturing firms. The structure of this sample is consistent with the initial COI 2006 database, in terms of specific industrial affiliation and firm size.

Compared with CIS data, COI data offer several advantages. Most notably, they provide a more objective measure of innovation, in line with a firm-level concept of newness (Aiken, Hage, 1971 ; Van de Ven, 1986). Each respondent firm indicated whether it used new lean management practices in 2003 and 2006. Moreover, the variables are available for all firms, whether they are considered innovative or not.

\section{Measures}

We provide a detailed description of the variables used in our empirical analysis in Table 1.

\section{Dependent variable}

Lean management (Womack et al., 1990), inspired by the Toyota Production System (Ohno, 1988), is one of the most notable MIs of the past two decades (Armbruster et al., 2008 ; Reichstein , Salter, 2006). As a well-established, significant MI (Armbruster, et al., 2008 ; Hamel, 2006), lean management has served as a useful proxy in many innovation studies (Mazzanti et al., 2006 ; Mol, Birkinshaw, 2009 ; OECD, 2005 ; Reichstein , Salter, 2006). It refers to a new form and new practices of workplace organization that focus on reducing waste without compromising on quality (Ohno, 1988 ; Womack, et al., 1990). It encompasses several specific practices, including just-in-time (JIT) sourcing, quality systems, self-directed work teams, pull production systems, quick changeover techniques and lot size reduction (Shah, Ward, 2003). The COI survey provides detailed information about seven lean management practices in 2006 and how they changed since 2003. Accordingly, we can compute a more 'objective' measure of innovation that involves the concept of newness at the firm level (Aiken , Hage, 1971 ; Rogers, 1995), unlike previous approaches that mainly address the firm's innovation perceptions at a given time. Thus, we derived our MI measure from seven Lean management indicators: (1) certification or accreditation of a quality system (ISO9001), (2) certification for environment or ethical labelling (ISO 14001), (3) a set of problem-solving tools, (4) independent work groups or teams, (5) JIT production, (6) traceability tools and (7) supply chain management tools and applications. These indicators align with key practices identified in lean management literature (Shah, Ward, 2003). The dependent variable $M I$ adoption intensity refers to the number of lean practices firms adopted between 2003 and 2006. We computed, for each firm, the sum of practices in use in 2003 and then in 2006, then calculated the difference. Each firm receives a score from 0 to 7 . Because few firms appeared 
in the three classes on the right tail of the distribution, we grouped them into a single class, such that each firm earned a score from 0 to 3 .

\section{Independent variables}

In accordance with the rational perspective, the first exploratory variables include both external sources of knowledge and absorptive capacity.

External sources: The breadth variable, reflecting firms' openness, indicates five external knowledge sources that firms might search and use: customers, private R\&D partnerships and suppliers, public R,D partnerships, consultants and external design advice services. In line with Laursen and Salter (2006), we compute the sum of sources used by each firm in 2006, so the measure can take a value from 0 , if the firm uses no external knowledge sources, to 5 , if it uses all of them.

Absorptive capacity: The absorptive capacity variables result from a cluster analysis. Similar to Dubouloz and Bocquet (2013), Escribano, et al. (2009) and Kostopoulos, et al.(2011), we used a principal component analysis to capture its multidimensionality(Lane, et al., 2006 ; Murovec, Prodan, 2009; Roberts et al., 2012 ; Zahra, George, 2002). Indeed, Flatten, Engelen, Zahra and Brettel (2011) argue that the use of single, static proxies may contribute to conflicting, misleading findings about its nature and contributions. Furthermore, because MI is relatively less associated with technological elements (Edquist, et al., 2001), an single R\&D proxy would not be sufficient to measure it. A more accurate operationalization would identify the different components and sub-components of absorptive capacity and determine their potential measures. Following Lane, et al. (2006) suggestions for operationalising absorptive capacity, we examine the components of the three dimensions (identify, assimilate and apply) that underlie this concept in Cohen and Levinthal's $(1989,1990,1994)$ studies (see Appendix A).

Accordingly, for the principal component analysis we used seven sub-variables to capture absorptive capacity fully. The $R \& D$ variable that corresponds to the main measure of absorptive capacity in the innovation literature equals 1 if there is an internal team dedicated to R\&D. Then prior_MI summarises the prior adoption of managerial practices, according to the sum of lean practices in use in 2003, such that it reflects the path-dependent nature of absorptive capacity (Cohen, Levinthal, 1990 ; Zahra, George, 2002). Specia equals 1 if the number of specialists ${ }^{2}$ is greater than the sample median, because that level implies the firm has relevant specialists who are competent in their field (Cohen, Levinthal, 1990). To value and assimilate new knowledge and ideas, the firm needs ICT (Chiaroni, et al., 2010 ; Cohen, Levinthal, 1990), so we used three variables to measure the IT infrastructure of each firm in 2006 (Todorova, Durisin, 2007): extranet network (extra), intranet network (intra), and electronic data interchange (EDI) (edi) system. Finally, we measured centralisation with centra, for which we calculated the sum of decisions made by the firm's top hierarchy in 2006, then compared it with the sample median. Centra equals 1 if the hierarchy managed more than four decision missions. These seven variables pertain to three factors that summarise the dimensions of absorptive capacity (62.23\% of total variance). We conducted a non-hierarchical cluster analysis on the scores revealed by our factor analysis. To determine the final number of clusters, we used three well-known criteria: (1) the statistical accuracy of the classification, measured by the ratio of within- and between-cluster variances (Fisher's test); (2) the number of firms per cluster; and (3) the economic significance of the identified clusters. According to these criteria, the version

\footnotetext{
${ }^{2}$ The focal specialties were design and R,D, purchases, sales and distribution, manufacture and operations, IT and data systems, human resources and training, and accounting, finance and management control.
} 
with two clusters of firms is preferable ${ }^{3}$.To interpret the two clusters, we calculated the mean of each absorptive capacity indicator in each cluster (see Appendix B), then compared the means for each cluster. In Cluster 1 (2164 firms), firms are well-equipped with EDI and extranet and intranet networks, and they have significant prior experience in organizational change. They also are more centralised. Cluster 2 (2155 firms) consists of firms with an internal R\&D team and relevant specialists in various fields. In turn, we include two dummy variables — value (reflecting the absorptive capacity "value" dimension from Cohen and Levinthal, 1989, 1990) and assapp ("assimilate" and "apply" dimensions from Cohen and Levinthal, 1989, 1990)—in the econometric analysis.

We then introduce three explanatory variables for the institutional pressures being considered in our theoretical framework.

Coercive pressures: Following Chen, et al., (2011), we measure coercive pressures using an inducement-based mode, with the prediction that an organization develops dependence on certain customers and suppliers when these supply chain partners account for most of its sales or purchases and are hard to replace with others. We introduce two variables to capture coercive pressures: Client concentration takes a value of 1 if the three main clients of the firm account for more than $50 \%$ of its total sales, and 0 otherwise; supplier concentration equals 1 when the three main suppliers account for more than $50 \%$ of total purchases, and 0 otherwise.

Mimetic pressures: Following Bocquet, et al., (2007) and Chen, et al. (2011), we measure mimetic effects using a frequency-based mode, based on the number of current adopters. We calculate the percentage of firms that adopted new lean practices in use in 2006 among the total number of firms in the sample that operate in the same industry. This variable is labelled mimetism.

Legitimation motivation: Following Tsinopoulos, et al. (2018), we measure motivation to achieve legitimacy with an item asking firms about the importance of process and work methods standardization in all the firm's decision.

Furthermore, given our estimation model (Zero-Inflated Poisson model, see below) we also consider two key predictors of the non-adoption of MI.

Techno_prio refers to the firm's technology focus. It equals 1 when technological modernity is important for the firm; this trait could hinder the adoption of MI and favour its non-adoption (zero-inflated class), because specialists' attention focuses more on technological innovation than MI(Birkinshaw, et al., 2008). Res_lack indicates the lack of human or financial resources faced by the firm $(1=$ firm perceives such difficulties, $0=$ otherwise $)$. Innovative firms tend to express greater awareness of these obstacles than non-innovative ones but also are better able to overcome them (Baldwin, Lin, 2002 ; Galia, Legros, 2004), so we expect a negative impact on the likelihood of being a non-adopter.

\section{Control variables}

Finally, we used two main variables to control for firm characteristics that could affect MI adoption. Larger firms are more likely to adopt managerial innovations, because they have more resources and better access to information (Huang, Rice, 2012 ; Kimberly, Evanisko, 1981 ; Schmidt, Rammer, 2007 ; Wischnevsky, et al., 2011). To measure firm size, we used the logarithm of the number of employees in 2006. With the dummies high_medium_tech and low_tech, we also controlled for within-industry heterogeneity.

${ }^{3}$ For all comparisons of variances that we report, the Fisher's test was significant at the 0.000 level and indicated a good differentiation of the firms. 


\section{Methodology}

Poisson regression models provide a standard framework for analysing count data, though these data often are over-dispersed (i.e., their variance exceeds their mean), which reduces the usefulness of a Poisson distribution. The summary statistics of the dependent variable (managerial_intensity) appears in Table 2, along with the distribution of frequencies, means and standard deviations. The distribution clearly shows an excess of zeros relative to a Poisson distribution, with a mean of 0.36 . To account for this over-dispersion, a modified zero-inflated Poisson (ZIP) regression model depicts the variance-mean relationship (Cameron, Trivedi, 2013 ; Heilbron, 1994 ; Lambert, 1992 ; Mullahy, 1986 ; Winkelmann, 2010). The data for this model come from two regimes: In $\mathrm{R}_{\mathrm{I}}$, the outcome is always a zero count, whereas in $\mathrm{R}_{\mathrm{II}}$, the counts follow a standard Poisson process. This over-dispersion arises not from heterogeneity, as is the case when the Poisson model is generalised to a negative binomial form, but rather from splitting the data into the two regimes. In practice, the presence of over-dispersion may reflect one or both sources (Greene, 2011 ; Mullahy, 1986). Thus, we model:

$$
\begin{aligned}
& \operatorname{Prob}\left(y_{i}=0 x_{i}\right)=\operatorname{Prob}\left(R_{I}\right)+\operatorname{Prob}\left(y_{i}=0 x_{i}, R_{I I}\right) \operatorname{Prob}\left(R_{I I}\right), \\
& \operatorname{Prob}\left(y_{i}=j x_{i}\right)=\operatorname{Prob}\left(y_{i}=j x_{i}, R_{I I}\right) \operatorname{Prob}\left(R_{I I}\right), j=1,2, \ldots n .
\end{aligned}
$$

If we let $z$ be a binary indicator of $\mathrm{R}_{\mathrm{I}}(z=0)$ or $\mathrm{R}_{\mathrm{II}}(z=1)$ and $y$ indicate the result of the Poisson model in $\mathrm{R}_{\mathrm{II}}$, the observed $y$ is equal to $z \times y^{*}$. A natural extension of the model with two regimes determines $z$ according to a set of covariates that may differ from the covariates that generate the conditional probabilities of the random process. Therefore,

$$
\begin{gathered}
\operatorname{Prob}\left(z_{i}=1 / w_{i}\right)=F\left(w_{i}, \lambda\right), \\
\operatorname{Prob}\left(y_{i}=j / x_{i}, z_{i}=1\right)=\frac{e^{-\lambda i} \lambda_{i}^{j}}{j !} .
\end{gathered}
$$

In turn, to handle the problem of excess zeros relative to the Poisson distribution, we propose the following ZIP model:

$$
\begin{aligned}
& \ln \lambda_{i}=\beta_{1} \text { breadt } \\
& +
\end{aligned}
$$




\section{Table 1. Variables used in the empirical analysis}

\begin{tabular}{|c|c|c|c|}
\hline Variables & Label & Description & Codification \\
\hline \multicolumn{4}{|l|}{ Dependent variable } \\
\hline $\begin{array}{l}\text { Managerial innovation } \\
\text { adoption intensity }\end{array}$ & MI_intensity & $\begin{array}{l}\text { Adoption intensity of seven new lean management practices (certification for quality, certification for environmental } \\
\text { labelling, set problem solving, independent work groups, JIT production, traceability tools, supply chain management } \\
\text { tools) during } 2003-2006.0=\text { no lean practice adopted; } 1=\text { one lean practice adopted; } 2=\text { two lean practices adopted, } \\
\text { and } 3=\text { three lean practices adopted or more than three. }\end{array}$ & Ordinal 0-3 \\
\hline \multicolumn{4}{|l|}{ Independent variables } \\
\hline Openness intensity & breadth & $\begin{array}{l}\text { Sum of five external sources of knowledge: clients or customers, consultants, private partners (private businesses or } \\
\text { laboratories), public partners (CNRS, universities, other public bodies), and external advice services to improve } \\
\text { design or R\&D. Each source is first coded as a binary variable }(0=\text { no use, } 1=\text { use). The addition of all source scores } \\
\text { leads to an overall score from } 0 \text { (no knowledge sources used) to } 5 \text { (all knowledge sources used). }\end{array}$ & Scale $0-5$ \\
\hline \multirow[t]{2}{*}{ Absorptive capacity } & value & $\begin{array}{l}\text { Equal to } 1 \text { if the firm has been classified in the absorptive capacity 'value' dimension from Cohen and Levinthal and } \\
0 \text { otherwise. }\end{array}$ & Dummy 0-1 \\
\hline & $\operatorname{assap}($ ref.) & $\begin{array}{l}\text { Equal to } 1 \text { if the firm has been classified in the absorptive capacity 'assimilate and apply' dimensions from Cohen } \\
\text { and Levinthal and } 0 \text { otherwise. }\end{array}$ & Dummy 0-1 \\
\hline Client concentration & $\begin{array}{l}\text { client } \\
\text { concentration }\end{array}$ & Equal to 1 if the three main clients constitute more than $50 \%$ of turnover, and 0 otherwise. & Dummy 0-1 \\
\hline Supplier concentration & $\begin{array}{l}\text { supplier } \\
\text { concentration }\end{array}$ & Equal to 1 if the three main suppliers weight more that $50 \%$ of total purchases and 0 otherwise. & Dummy 0-1 \\
\hline Mimetic effects & mimetism & $\begin{array}{l}\text { Percentage of firms which have adopted new lean practices in } 2006 \text { among the total number of firms in the sample } \\
\text { which operate in the same industry }\end{array}$ & Continuous \\
\hline Legitimation motivation & legitimation & Equal to 1 if legitimation motivation is of great importance (high or very high) in decision-making and 0 otherwise & Dummy 0-1 \\
\hline Lack of resources & res_lack & Equal to 1 if the firm perceives a lack of human or financial resources in 2006 and 0 otherwise. & Dummy 0-1 \\
\hline Technological focus & techno_prio & Equal to 1 if technological modernity is of great (high or very high) importance for the firm and 0 otherwise. & Dummy 0-1 \\
\hline \multicolumn{4}{|l|}{ Control variables } \\
\hline Size & Size & Logarithm of the number of employees. & Logarithm \\
\hline Low-tech industries & low_tech & Equal to 1 if the firm belongs to low-tech manufacturing sectors and 0 otherwise. & Dummy 0-1 \\
\hline High-medium tech industries & $\begin{array}{l}\text { high_medium } \\
\text { tech (ref.) }\end{array}$ & Equal to 1 if the firm belongs to high or medium-tech manufacturing sectors and 0 otherwise. & \\
\hline
\end{tabular}


As Lambert (1992) shows, it is convenient to specify the two-regime model using logit, with the covariates $X=\{$ breadth, breadth_squared, value, breadth_value, client concentration, supplier concentration, mimetism, legitimation motivation, techno_prio, res_lack, size, low_tech\}. We computed a Vuong test of the superiority of the model with two regimes compared with a classical Poisson regression model and the zero-inflated negative binomial regression model $^{4}$. This test clearly supports the use of the ZIP model ( $t$-statistic $=8.17,95 \%$ confidence limit), because the large positive value is greater than the threshold of 1.96.

Table 2. Intensity of Managerial innovation adoption

\begin{tabular}{cc}
\hline \hline 0 & $3278(75.90 \%)$ \\
1 & $654(15.14 \%)$ \\
2 & $251(5.81 \%)$ \\
3 & $136(3.15 \%)$ \\
\hline Number of observations & 4319 \\
Mean & 0.36 \\
Standard deviation & 0.73 \\
\hline
\end{tabular}

\section{RESULTS}

Our results confirm most of the hypotheses, in support of the strength of the arguments derived from both rational and institutional perspectives (Table 3). Thus, we conclude that MI adoption is influenced by both an active external search strategy and external pressures.

According to the rational perspective, a firm opens its innovation process through deliberate actions. Our results confirm that a voluntary acquisition strategy favours MI intensity. More precisely, we note a significant and positive effect of breadth $(\beta=.589, p<.001)$ on the number of MIs adopted by the firm. Although breadth squared also has a significant effect $(\beta=.069$, $p<.001$ ), its sign is negative. Therefore, we find a threshold, above which the use of external knowledge sources generates decreasing returns, in support of $\mathrm{H} 1$.

$\mathrm{H} 2$, which is related to the positive impact of absorptive capacity on MI adoption intensity is supported, because the coefficient for the absorptive capacity variable is significant and positive $(\beta=.507, p<.001)$. Our results also support $\mathrm{H} 3$ : the interaction of external knowledge source breadth and absorptive capacity reveals a significant, negative effect $(\beta=.154, p<.001)$ on the number of new MIs adopted by the firm.

With respect to $\mathrm{H} 4$, the effects of coercive pressures on MI adoption intensity are partially demonstrated. The concentration of clients has a significant positive effect $((\beta=.176 \mathrm{p}<.01)$ while the role of key suppliers is not significant. The estimation results do not support $\mathrm{H} 5$ related to mimetic effects. By contrast, they confirm the role of firms' quest of legitimacy ${ } \beta=$ $.126, \mathrm{p}<.01)$ on the number of MI they adopt.

For the zero state (i.e., probability that firms adopt no MI), the parameters for the lack of resources and technological strategy focus are all highly significant $(p<.001)$, with negative signs. Therefore, firms that perceive financial or human constraints have a lesser probability of not being innovative. Manufacturing firms focused on technological modernity also are less likely to appear in the zero class.

\footnotetext{
${ }^{4} \mathrm{We}$ also ran a zero-inflated negative binomial regression model (ZINB). To compare the ZIP with the ZINB, we applied the Vuong test. The resulting t-statistics of 8.41 for the ZIP model confirmed that it provided the best overall fit, so we discuss the results only for the ZIP model.
} 
Table 3. ZIP model estimation results

\begin{tabular}{|c|c|c|c|}
\hline & \multicolumn{3}{|c|}{ ZIP } \\
\hline & $\begin{array}{c}\text { Parameter estimate } \\
(t \text {-statistic })\end{array}$ & & $\begin{array}{c}\text { Marginal effects } \\
(t \text {-statistic })\end{array}$ \\
\hline \multicolumn{4}{|l|}{ Count state } \\
\hline Constant term & $-1.599 * * *(0.19)$ & & \\
\hline Openness intensity (breadth) & $0.589 * * *(0.071)$ & & $0.194 * * *(0.022)$ \\
\hline Breadth_squared & $-0.069 * * *(0.014)$ & & $-0.024 * * *(0.001)$ \\
\hline Absorptive capacity & $0.507 * * *(0.123)$ & & $0.179 * * *(0.04)$ \\
\hline Breadth $\times$ Absorptive capacity & $-0.154 * * *(0.043)$ & & $-0.051 * * *(0.014)$ \\
\hline Client concentration & $0.176 * * *(0.060)$ & & $0.059 * * *(0.021)$ \\
\hline Supplier concentration & $-0.017(0.066)$ & & $-0.005(0.022)$ \\
\hline Mimetism & $0.010(0.006)$ & & $0.003(0.002)$ \\
\hline Legitimation & $0.126 * *(0.072)$ & & $0.040 *(0.023)$ \\
\hline Low-tech industries & $0.209 * * *(0.064)$ & & $0.071 * * *(0.022)$ \\
\hline Firm size & $0.014(0.025)$ & & $0.004(0.008)$ \\
\hline Lack of resources & & & $0.144 * * *(0.029)$ \\
\hline Technological focus & & & $0.070 * * *(0.023)$ \\
\hline \multicolumn{4}{|l|}{ Zero state } \\
\hline Constant term & $0,485 * * *(0.13)$ & & \\
\hline Lack of resources & $-0.883 * * *(0.196)$ & & \\
\hline Technological focus & $-0.419 * * *(0.136)$ & & \\
\hline Log-likelihood at convergence, $L L(\beta)$ & \multicolumn{3}{|c|}{-3159.39} \\
\hline Number of observations & \multicolumn{3}{|c|}{4160} \\
\hline Number of nonzero observations & \multicolumn{3}{|c|}{1018} \\
\hline Vuong test & \multicolumn{3}{|c|}{$8.17 * * *$} \\
\hline
\end{tabular}

Notes: Robust standard errors are reported in round brackets.

$* * *$ Significant at 0.001. ** Significant at 0.01. * Significant at 0.05. $\uparrow$ Significant at 0.10. 
Finally, with regard to the control variables, low-tech manufacturing firms are more likely to introduce new managerial practices, but the effect of size is not significant.

\section{DISCUSSION AND CONCLUSION}

This article advances two perspectives to understand the extent to which openness affects the intensity of MI adoption. Following Poole and Van de Ven's (1989) recommendations, our approach exploits the paradoxes created by distinct assumptions across two different perspectives to capture the complexity of innovation adoption. Similar to Abrahamson (1991), we conclude that this paradox resolution can effectively explain the adoption of MI, in that both institutional and rational perspectives capture some drivers of MI adoption. Accordingly, we show that MI adoption is driven by deliberate actions, but also by the pursuit of legitimacy or external pressures. Despite these different mechanisms for external knowledge acquisition, firms still face internal obstacles that hamper their MI adoption.

\section{Impact of openness on MI adoption}

Firms can engage in active external searches to find and introduce new managerial practices that promise to enhance their performance (Mol, Birkinshaw, 2009). Using the concept of breadth (Laursen, Salter, 2006), and in line with Damanpour, et al. (2018)'s results in the context of public organizations, we find that the degree of openness to external sources fosters the adoption of MI in private companies. Our results go one step further by showing that this effect is observed up to a tipping point, after which its impact becomes negative. These findings are consistent with research by Laursen and Salter (2006) and Huang and Rice (2012), in reference to technological innovations or process innovations. They reinforce the open innovation model, because firms that are open to external sources benefit from additional external knowledge. Such external knowledge sources are not always easy to access though (Clausen, 2013 ; Flor, et al., 2018). Two difficulties related to attention dynamics might limit the benefits of external knowledge breadth. That is, when there are too many ideas, firms have trouble attending sufficiently to all of them. Because they must focus on a few, firms tend to choose those that are closer to their existing organizational routines. Furthermore, ideas might arrive at the wrong time or in the wrong place, such that the firms lack the necessary capacities to value, explore and exploit them (Ocasio, 1997). In such cases, too much openness can be counterproductive to MI adoption. This discussion underlines the importance of the degree of openness for the beneficial outcomes of breadth. Faced with vast information and knowledge, firms must be able to select, assimilate and apply the most pertinent, which requires a strong absorptive capacity.

\section{Ambiguous role of absorptive capacity}

Previous conceptual and empirical research recommends making absorptive capacity an additional dimension of open innovation and accounting for its positive effects on innovation adoption(Clausen, 2013 ; Lichtenthaler, Lichtenthaler ; 2009 ; Robertson, et al., 2012). We confirm its positive effect on MI. However, the combined measure of breadth and absorptive capacity has a negative impact, which implies a substitution effect (Laursen, Salter, 2006). Because a joint investment in absorptive capacity and openness can be costly and time consuming, some firms, especially smaller ones with insufficient resources, may be forced to 
trade-off between the two activities (Clausen, 2013 ; Robertson, et al., 2012). Because MI influence firms' performance less readily than do technological innovations (Damanpour, Evan, 1984 ; Ettlie, Reza, 1992), firms might be less prone to make significant investments in openness and absorptive capacity in this context. The not-invented-here (NIH) syndrome also might induce this substitution effect. Defined as "the tendency of project group of stable composition to believe it possesses a monopoly of knowledge of its field, which leads it to reject new ideas from outsiders" (Katz, Allen, 1982, p. 7), the NIH syndrome causes firms to privilege internal absorptive capacity mechanisms over external knowledge. Some research also suggests that NIH exists at the organizational level, manifested as internal resistance to external knowledge (Wastyn, Hussinger, 2011). If NIH syndrome dominates, open innovation requires significant changes to the organization's culture, which cannot occur quickly or without human resource interventions.

\section{A new light on open managerial innovation: the institutional perspective}

While the rational-view of open innovation still prevails(Bogers, et al., 2017, Damanpour, et al., 2018), a key finding of this study is to show that external coercive pressures and the quest of legitimacy have also significant influence on the decision to adopt MI. In line with the institutional perspective, we demonstrate the role of social influence in shaping firms' actions. Different arguments can be put forward for such influence. First, firms develop a dependence on certain clients that exert significant pressures (Pfeffer, Salancik, 1978). The threat of sanction by these powerful actors provides strong incentives for conformity with lean practices (Meyer, Scott, 1992). By compelling firms to adopt such practices, dominant actors reap more benefits from their own adoption. Second, in an open innovation context, the MI adoption is also motivated by the desire to conform with established norms and standards to be legitimate. For instance, firms implement ISO14001standard because they desire to signal to external partners that they have a credible way of managing their environmental systems (Bansal, Hunter, 2003). For the lean management, firms, by this way, like to show to their customers that they are able to consistently provide the products they have promised assuring quality standards, monitoring of deadlines and workflow. As a result, they often openly publicize their external accreditations or lean management adoption to signal that they have robust and effective control mechanisms in place and are, in turn, legitimate organizations with which to do business (Dubouloz, 2012).Third, by contrast with previous studies(Lee , Pennings, 2002), our results also show that coercive effects are stronger than quest of legitimation while mimetism does not seem to have any effect (Lee, Pennings, 2002).A key factor to explain this result is the longer time required to imitate new managerial practices, because they must be tailored to each firm's environment and strategy (Teece, 1980). Another explanation is that our measure of mimetic effect, based on current adopters in the period 2003-2006, may be inadequate to capture the necessary time lag.

\section{Main contributions}

Taken together, these findings contribute to MI and open innovation literatures in several ways. From the MI literature, they firstly draw a more complete picture of the external antecedents and motives that influence the adoption of a still under-studied type of innovation. Second, empirical evidence that compares the relevance of fashion versus rational perspectives is scarce (Damanpour, 2012); our empirical study offers a rare quantitative exploration of the interplay of these two approaches to a firm's motivations for MI adoption. In turn, it enables us to confirm the ability of both perspectives to identify antecedents of MI adoption, while also providing more nuanced characterisations of both approaches. By explicitly considering coercive effects, 
mimetism and quest of legitimacy, we show that the decision to adopt MI does not relate solely to a rational approach. External pressures from clients and the quest of legitimacy also significantly influence the decision to adopt new managerial practices. These results suggest rebalancing the effects of institutional pressures and deliberate actions on the decision to adopt MI.

From the open innovation literature, this research enables a holistic examination of open innovation by analysing it from various perspectives and integrating alternate theories that are still outside the direct open innovation field (Randhawa, et al., 2016). Accordingly, we show that open innovation can be explained by deliberate actions (rational perspective), but also by the pursuit of legitimacy or external pressures (institutional perspective).Furthermore, in an systematic review of the literature on open innovation, Randhawa, et al. (2016) show that open innovation studies focus on technology, product development, R\&D, and licensing. These results are also supported by a more recent study, which stresses the need to broaden the scope of open innovation to process innovations rather than just product innovations. Our research responds to this call and offers a new path for research, in that it shows that open innovation can be also extended and apply to non-technological process innovations.

In methodological terms, this paper is a first attempt to provide a more objective measure of MI based on the difference between the number of practices adopted in year $t$ and year $t-3$. Such a measure can be considered as a response to some critics that have been opposed to CIS data. As quoted from Mairesse and Mohnen (2010), it is not always clear to the respondents what exactly is defined as a new or improved product, process, practice etc. Moreover, unlike prior research on absorptive capacity that used quite crude proxies, we construct a multidimensional measure building on two dimensions from Cohen and Levinthal's work(1990).

\section{Managerial implications, limitations and further research}

In addition to contributing to extant research, this study provides useful guidance for practitioners. It details the conditions in which firms' openness can foster MI innovation. Managers must realise that they can benefit from their environmental context and institutional pressures from their key clients. However, these sources are only part of the story. A deliberate external knowledge search strategy also is crucial to the adoption of new practices, processes or structures. Therefore, managers should fix their priorities and orient internal agents' efforts toward dedicated external sources, to avoid the decreasing returns associated with excessive openness. They also must address the risk of substitution between external knowledge sources and internal resources, keeping in mind that MI get implemented in contexts with strong cultures, such that internal resistance to change often is strong.

The limitations of this study also demand consideration. First, we rely on a specific MI, lean management, without offering any comparisons. This single-MI focus enabled us to test a welldeveloped concept, one that is both an influential MI (Reichstein, Salter, 2006) and a wellaccepted proxy (Mazzanti, et al., 2006 ; Mol, Birkinshaw, 2009 ; OECD, 2005 ; Reichstein, Salter, 2006). However, it also would be interesting to extend our model to other MIs. Second, previous research recommends including multiple innovation adoption phases (Damanpour, Schneider, 2006 ; Pierce, Delbecq, 1977), whereas we considered only the adoption/decision phase, without differentiating the effects of openness or absorptive capacity across distinct phases. Longitudinal research could address this limitation by empirically testing the causal relationships established in our model over time. Third, we endeavoured to introduce an accurate measure of absorptive capacity, consistent with Cohen and Levinthal's $(1989,1990)$ original formulations, to account for its multidimensional features. We also assessed the validity and reliability of our absorptive capacity measures, but they remain constrained by the COI survey data. Other studies could enhance this operationalisation by applying it to different 
datasets. Fourth, from an open innovation perspective of MI, our results show that openness to external sources such as clients or customers, consultants, private partners (private businesses or laboratories), public partners (CNRS, universities, other public bodies), and external advice services fosters the adoption of MI. In the light of these results, future studies might consider the specific role of these external actors, in particular consultants and researchers, using indepth qualitative research. Finally, in line with Le Roy et al. (2013), we expect that the accumulation of knowledge on MI adoption will contribute to its recognition and help firms to make MI a crucial lever of their performance. 


\section{REFERENCES}

ABRAHAMSON, E. (1991), Managerial Fads ans fashions: the diffusion and refection of innovations. Academy of Management Review, 16(3), 586-612.

ABRAHAMSON, E. (1996), Management Fashion. Academy of Management Review, 21(1), 254-285.

AIKEN, M., HAGE, J. (1971), The Organic Organization and Innovation, Sociology. 5, 63-82. ANDERSON, S. W., DALY, D., JOHNSON, M. F. (1999), Why firms seek ISO 9000 certification: Regulatory compliance or cometitive advantage. Production and Operations Management, 8(1), 28-43.

ARMBRUSTER, H., BIKFALVI, A., KINKEL, S., LAY, G. (2008), Organizational innovation: The challenge of measuring non-technical innovation in large-scale surveys. Technovation, 28(10), 644-657.

BALDWIN, J., LIN, Z. (2002), Impediments to advanced technology adoption for Canadian manufacturers. Research Policy, 31(1), 1-18.

BANSAL, P., HUNTER, T. (2003), Strategic Explanations for the Early Adoption of ISO 14001. Journal of Business Ethics, 46(3), 289-299.

BATTISTI, G., STONEMAN, P. (2010), How Innovative are UK Firms? Evidence from the Fourth UK Community Innovation Survey on Synergies between Technological and Organizational Innovations. British Journal of Management, 21, 187-206.

BIRKINSHAW, J., HAMEL, G., MOL, M. J. (2008), Management innovation. Academy of Management Review, 33(4), 825-845.

BIRKINSHAW, J., MOL, M. J. (2006), How management innovation happens. Sloan Management Review, 47(4), 81-88.

BOCQUET, R., BROSSARD, O., SABATIER, M. (2007), Complementarities in organizational design and the diffusion of information technologies: An empirical analysis. Research Policy, 36(3), 367-386.

BOER, H., DURING, W. E. (2001), Innovation, what innovation? A comparison between product, process and organizational innovation. International Journal of Technology Management, 22(1/2/3), 83-107.

BOGERS, M., ZOBEL, A.-K., AFUAH, A., ALMIRALL, E., BRUNSWICKER, S., DAHLANDER, L., FREDERIKSEN, L., GAWER, A., GRUBER, M., HAEFLIGER, S., HAGEDOORN, J., HILGERS, D., LAURSEN, K., MAGNUSSON, M. G., MAJCHRZAK, A., MCCARTHY, I. P., MOESLEIN, K. M., NAMBISAN, S., PILLER, F. T., RADZIWON, A. (2017), The open innovation research landscape: established perspectives and emerging themes across different levels of analysis. Industry and Innovation, 24(1), 8-40.

CAMERON, A. C., TRIVEDI, P. K. (2013), Regression analysis of count data (2nd ed.). Econometric Society Monograph No. 53, Cambridge, Cambridge University Press.

ČERNE, M., KASE, R., ŠKERLAVAJ, M. (2016), Non-technological innovation research : evaluating the intellectual structure and prospects of an emerging field. Scandinavian Journal of Management, 32(2), 69-85. 
CHEN, A. J., WATSON, R. T., BOUDREAU, M.-C., KARAHANNA, E. (2011), An Institutional Perspective on the Adoption of Green IS, IT. Australasian Journal of Information Systems, 17(1), 5-27

CHESBROUGH, H. (2012), Open Innovation : Where We've Been and Where We're Going, Research-Technology Management, 55(4), 20-27

CHESBROUGH, H. (2006), Open Innovation: A new paradigm for understanding industrial innovation. In W. V. J. W. Edited by Henry Chesbrough (Ed.), Open Innovation: Researching a new paradigm: 1-12: Oxford University Press.

CHIARONI, D., CHIESA, V., FRATTINI, F. (2010), Unravelling the process from Closed to Open Innovation: evidence from mature, asset-intensive industries. $R \& D$ management, $40(3)$, 222-245.

CIS (2010), The Community Innovation Survey. Luxembourg: Eurostat.

CLAUSEN, T. H. (2013), External knowledge sourcing from innovation cooperation and the role of absorptive capacity: empirical evidence from Norway and Sweden. Technology Analysis, Strategic management, 25(1), 57-70.

COHEN, W. M., LEVINTHAL, D. A. (1989), Innovation and Learning: The Two Faces of R\&D. The Economic Journal, 99(397), 569-596.

COHEN, W. M., LEVINTHAL, D. A. (1990), Absorptive Capacity: A New Perspective on Learning and Innovation. Administrative Science Quarterly, 35(1), 128-152.

COHEN, W. M., LEVINTHAL, D. A. (1994), Fortune Favors the Prepared Firm. Management Science, 40(2), 227-251.

CROSSAN, M. M., APAYDIN, M. (2010), A Multi-Dimensional Framework of Organizational Innovation: A Systematic Review of the Literature. Journal of Management Studies, 47(6), 1154-1191.

DAHLANDER, L., GANN, D. M. (2010), How open is innovation ? Research Policy, 39(6), 699-709.

DAMANPOUR, F. (2012), Footnotes to research on managerial innovation, EURAM Miniconference on Management Innovation, $6^{\text {th }}-8^{\text {th }}$ june. Rotterdam.

DAMANPOUR, F., ARAVIND, D. (2012), Managerial Innovation: Conceptions, Processes, and Antecedents. Management \& Organization Review, 8(2), 423-454.

DAMANPOUR, F., EVAN, W. M. (1984), Organizational Innovation and Performance: The Problem of "Organizational Lag". Administrative Science Quarterly, 29(3), 392-409.

DAMANPOUR, F., SANCHEZ-HENRIQUEZ, F., CHIU, H. H. (2018), Internal and External Sources and the Adoption of Innovations in Organizations. British Journal of Management, $1-19$.

DAMANPOUR, F., SCHNEIDER, M. (2006), Phases of the Adoption of Innovation in Organizations: Effects of Environment, Organization and Top Managers. British Journal of Management, 17(3), 215-236.

DANIEL, E., MYERS, A., DIXON, K. (2012), Adoption rationales of new management practices. Journal of Business Research, 65(3), 371-380.

DIMAGGIO, P. J., POWELL, W. W. (1983), The iron cage revisited: Institutional isomorphism and collective rationality in organizational fields. American Sociological Review, 48(2), $147-$ 160 . 
DUBOULOZ, S. (2012), Organizational innovation: Clarifying the concept as output and as process and suggesting research avenues, AIMS - International Association of Strategic Management. Lille, France.

DUBOULOZ, S., BOCQUET, R. (2013), Innovation organisationnelle : S'ouvrir pour innover plus. Revue Française de Gestion, 39(235), 129-147.

EDQUIST, C., HOMMEN, L., MCKELVEY, M. (2001), Innovation and employment: Process versus product innovation. Cheltenham: Edward Elgar.

ESCRIBANO, A., FOSFURI, A., TRIBO, J. A. (2009), Managing external knowledge flows: The moderating role of absorptive capacity. Research Policy, 38(1), 96-105.

ETTLIE, J. E., REZA, E. M. (1992), Organizational Integration and Process Innovation. The Academy of Management Journal, 35(4), 795-827.

EVAN, W. M. (1966), Organizational lag. Human Organizations, 25, 51-53.

EVAN, W. M., BLACK, G. (1967), Innovation in Business Organizations: Some Factors Associated with Success or Failure of Staff Proposals. The Journal of Business, 40(4), 519-530. FABRIZIO, K.R. (2009), Absorptive capacity and the search for innovation. Research Policy, 38(2), 255-267

FLATTEN, T. C., ENGELEN, A., ZAHRA, S. A., BRETTEL, M. (2011), A measure of absorptive capacity: Scale development and validation. European Management Journal, 29(2), 98-116.

FLOR, M. L., COOPER, S. Y., OLTRA, M. J. (2018), External knowledge search, absorptive capacity and radical innovation in high-technology firms. European Management Journal, 36(2), 183-194.

FRAMBACH, R. T., SCHILLEWAERT, N. (2002), Organizational innovation adoption. A multi-level framework of determinants and opportunities for future research. Journal of Business Research, 55, 163-176.

GALIA, F., LEGROS, D. (2004), Complementarities between obstacles to innovation: evidence from France. Research Policy, 33, 1185-1199.

GANTER, A., HECKER, H. (2013), Deciphering antecedents of organizational innovation. Journal of Business Research, 66(5), 575-584.

GASSMANN, O., ENKEL, E., CHESBROUGH, H. (2010), The future of open innovation. $R \& D$ management, 40(3), 213-221.

GREENE, W. H. (2011), GREENE W. (2011), Econométrie, Version française adaptée par Schlacther D., Azomahou T., Van P.-N. et Raymond W., $7^{\text {ème }}$ édition, New York, Pearson Education.

HAMEL, G. (2006), The Why, What, and How of Management Innovation. Harvard Business Review, 84(2), 72-84.

HEILBRON, D. C. (1994), Zero-Altered and other Regression Models for Count Data with Added Zeros. Biometrical Journal, 36(5), 531-547.

HUANG, F., RICE, J. (2012), Openness in product and process innovation. International Journal of Innovation Management, 16(4), 1-24.

HUIZINGH, E. K. R. E. (2011), Open innovation: State of the art and future perspectives. Technovation, 31(1), 2-9.

KATZ, R., ALLEN, T. (1982), Investigating the Not Invented Here (NIH) syndrome: A look at the performance, tenure, and communication patterns of $50 \mathrm{R} \& \mathrm{D}$ Project Groups. $R \& D$ management, 12(1), 7-20. 
KEUPP, M. M., PALMIE, M., GASSMANN, O. (2011), The Strategic Management of Innovation: A Systematic Review and Paths for Future Research International Journal of Management Reviews, 14(4), 367-390

KIMBERLY, J. R., EVANISKO, M. J. (1981), Organizational Innovation: The influence of individual, organizational, and contextual factors on hospital adoption of technological and administrative innovations. Academy of Management Journal, 24(4), 689-713.

KOSTOPOULOS, K., PAPALEXANDRIS, A., PAPACHRONI, M., IOANNOU, G. (2011), Absorptive capacity, innovation, and financial performance. Journal of Business Research, 64(12), 1335-1343.

LAMBERT, D. (1992), Zero-Inflated Poisson Regression, with an Application to Defects in Manufacturing. Technometrics, 34(1), 1-14.

LANE, P. J., KOKA, B. R., PATHAK, S. (2006), The Reification of Absorptive Capacity: A Critical Review and Rejuvenation of the Construct. The Academy of Management Review, 31(4), 833-863.

LANE, P. J., LUBATKIN, M. (1998), Relative Absorptive Capacity and Interorganizational Learning. Strategic Management Journal, 19(5), 461-477.

LAURSEN, K., SALTER, A. (2006), Open for innovation: the role of openness in explaining innovation performance among U.K. manufacturing firms. Strategic Management Journal, 27(2), 131-150.

LAZZAROTTI, V., MANZINI, R. (2009), Different modes of open innovation: a theoretical framework and an empirical study. International Journal of Innovation Management, 13(4), 615-636.

LE ROY, F., ROBERT, M., GIULIANI, P. (2013), L'innovation managériale. Généalogie, défis et perspectives. Revue Française de Gestion, 6(235), 77-90.

LEE, K., PENNINGS, J. M. (2002), Mimicry and the market: adoption of a new organizational form. Academy of Management Journal, 45(1), 144-162.

LENOX, M., KING, A. (2004), Prospects for Developing Absorptive Capacity through Internal Information Provision. Strategic Management Journal, 25(4), 331-345.

LICHTENTHALER, U. (2011), Open Innovation: Past Research, Current Debates, and Future Directions. Academy of Management Perspectives, 25(1), 75-93.

LICHTENTHALER, U., Lichtenthaler, E. (2009), A Capability-Based Framework for Open Innovation: Complementing Absorptive Capacity. Journal of Management Studies, 46(8), 1315-1338.

LIN, H.-F., SU, J.-Q., HIGGINS, A. (2016), How dynamic capabilities affect adoption of management innovations. Journal of Business Research, 69(2), 862-876.

LOILIER, T., TELLIER, A. (2011), Que faire du modèle de l'innovation ouverte ? Revue Française de Gestion, 1(210), 69-85.

MAIRESSE, J., MOHNEN, P. (2010), Chapter 26 - Using Innovation Surveys for Econometric Analysis. In B. H. Hall, N. Rosenberg (Eds.), Handbook of the Economics of Innovation, Vol. 2, North-Holland.

MATIAS, J. C. D. O., COELHO, D. A. (2002), The integration of the standards systems of quality management, environmental management and occupational health and safety management. International Journal of Production Research, 40(15), 3857-3866. 
MAZARS-CHAPELON, A., CHAPELLIER, P., MIGNON, S. (2018), The generation of management innovation in microentreprises: absorptive capacity and entrepreneur-CPA relationship. International Journal of Entrepreneurship and Small Business, 35(1).

MAZZANTI, M., PINI, P., TORTIA, E. (2006), Organizational innovations, human resources and firm performance: The Emilia-Romagna food sector. Journal of Socio-Economics, 35(1), 123-141.

MEYER, J., SCOTT, W. (1992), Organizational environments, Sage Publications, Newbury Park, CA.

MOL, M. J., BIRKINSHAW, J. (2009), The sources of management innovation: When firms introduce new management practices. Journal of Business Research, 62(12), 1269-1280.

MOL, M. J., BIRKINSHAW, J. (2014), The Role of External Involvement in the Creation of Management Innovations. Organization Studies, 35(9), 1287-1312.

MULLAHY, J. (1986), Specification and testing of some modified count data models. Journal of Econometrics, 33(3), 341-365.

MUROVEC, N., PRODAN, I. (2009), Absorptive capacity, its determinants, and influence on innovation output: Cross-cultural validation of the structural model. Technovation, 29(12), 859872.

OCASIO, W. (1997), Towards an attention-based view of the firm. Strategic Management Journal, 18, 187-206.

OECD (2005), Oslo Manual: Guidelines for collecting and interpreting innovation data, OECD and Eurostat.

OHNO, T. (1988), Toyota Production System : Beyond Large Scale Production, Productivity Press. New York.

PFEFFER, J., SALANCIK, G. R. (1978), The external control of organizations: A resource dependence perspective, Harper \& Row, New York.

PIERCE, J., L., DELBECQ, A. L. (1977), Organization Structure, Individual Attitudes and Innovation. The Academy of Management Review, 2(1), 27-37.

POLDER, M., VAN LEEUWEN, G., MOHNEN, P., RAYMOND, W. (2010), Product, process and organizational innovation: drivers, complementarity and productivity effects, United Nations University Working paper series.

POOLE, M. S., VAN DE VEN, A. H. (1989), Using Paradox to Build Management and Organization Theories. Academy of Management Review, 14(4), 562-578.

RADNEJAD, A. B., VREDENBURG, H., WOICESHYN, J. (2017), Meta-organizing for open innovation under environmental and social pressures in the oil industry. Technovation, 66, 1427.

RANDHAWA, K., WILDEN, R., HOHBERGER, J. (2016), A Bibliometric Review of Open Innovation: Setting a Research Agenda. Journal of Product Innovation Management, 33(6), 750-772.

REICHSTEIN, T., SALTER, A. (2006), Investigating the sources of process innovation among UK manufacturing firms. Industrial and Corporate Change, 15(4), 653-682.

ROBERTS, N., GALLUCH, P. S., DINGER, M., GROVER, V. (2012), Absorptive capacity and information systems research: review, synthesis, and directions for future research. MIS Quarterly, 36(2), 625-A626. 
ROBERTSON, P. L., CASALI, G. L., JACOBSON, D. (2012), Managing open incremental process innovation: Absorptive Capacity and distributed learning. Research Policy, 41, 822832.

ROGERS, E. (1995), Diffusion of innovations, New York, Free Press.

ROSENBERG, N. (1982), Inside the Black Box, Cambridge University Press, Cambridge, MA. SCHMIDT, T., RAMMER, C. (2007), Non-technological and Technological Innovation: Strange Bedfellows? Paper presented at the ZEW Zentrum für Europäische Wirtschaftsforschung GmbH.

SHAH, R., WARD, P. T. (2003), Lean manufacturing: context, practice bundles, and performance. Journal of Operations Management, 21, 129-149.

SHERER, P. D., LEE, K. (2002), Institutional change in large law firms: a resource dependency and institutional perspective. Academy of Management Journal, 45(1), 102-119.

STAW, B. M., EPSTEIN, L. D. (2000), What Bandwagons Bring: Effects of Popular Management Techniques on Corporate Performance, Reputation, and CEO Pay. Administrative Science Quarterly, 45, 523-556.

TEECE, D. J. (1980), The Diffusion of an Administrative Innovation. Management Science, 26(5), 464-470.

TODOROVA, G., DURISIN, B. (2007), Absorptive Capacity: Valuing a Reconceptualization. The Academy of Management Review, 32(3), 774-786.

TSINOPOULOS, C., SOUSA, C. M. P., YAN, J. (2018), Process Innovation: Open Innovation and the Moderating Role of the Motivation to Achieve Legitimacy. Journal of Product Innovation Management, 35(1), 27-48.

UTTERBACK, J. M., ABERNATHY, W. J. (1975), A dynamic model of process and product innovation. Omega, 3(6), 639-656.

VACCARO, I. G., JANSEN, J. J. P., VAN DEN BOSCH, F. A. J., VOLBERDA, H. W. (2012), Management Innovation and Leadership: The Moderating Role of Organizational Size. Journal of Management Studies, 49(1), 28-51.

VAN DE VEN, A. H. (1986), Central problems in the management of innovation. Management Science, 32(5), 590-607.

VOLBERDA, H. W., VAN DEN BOSCH, F. A. J., HEIJ, C. V. (2013), Management Innovation: Management as Fertile Ground for Innovation. European Management Review, 10(1), 1-15.

WASTYN, A., HUSSINGER, K. (2011), In search for the Not-Invented-Here Syndrome: the role of knowledge sources and firm success, DRUID. Copenhagen Business School, Denmark.

WINKELMANN, R. (2010), Econometric Analysis of Count Data (Fifth ed.), Springer-Verlag Berlin and Heidelberg GmbH \& Co. K.

WISCHNEVSKY, J. D., DAMANPOUR, F., MENDEZ, F. A. (2011), Influence of Environmental Factors and Prior Changes on the Organizational Adoption of Changes in Products and in Technological and Administrative Processes. British Journal of Management, 22(1), 132-149.

WOMACK, J. P., JONES, D. T., ROOS, D. (1990), The machine that changed the world, The story of Lean Production, Scribner.

ZAHRA, S. A., GEORGE, G. (2002), Absorptive Capacity: A Review, Reconceptualization, and Extension. The Academy of Management Review, 27(2), 185-203. 


\section{Appendix A. Absorptive capacity (ACAP): Operationalisation issues}

\begin{tabular}{|c|c|c|c|c|}
\hline $\begin{array}{c}\text { ACAP dimensions(Cohen , } \\
\text { Levinthal, 1989, 1990, } \\
\text { 1994) }\end{array}$ & & Components & Cohen and Levinthal citations & $\begin{array}{l}\text { Measures ofabsorptive capacity } \\
\text { components }\end{array}$ \\
\hline $\begin{array}{l}\text { VALUE } \\
\text { A firm's ability to recognise } \\
\text { the value of new knowledge } \\
\text { and acquire it }\end{array}$ & - & $\begin{array}{l}\text { Communication } \\
\text { structures }\end{array}$ & $\begin{array}{l}\text { - A firm without a prior } \\
\text { technological base in a } \\
\text { particular field may not be } \\
\text { able to readily acquire one' } \\
\text { (1994: 236) } \\
\text { ACAP depends "on the } \\
\text { structure of communication } \\
\text { between the external } \\
\text { environment and the } \\
\text { organization" (1990:132) }\end{array}$ & 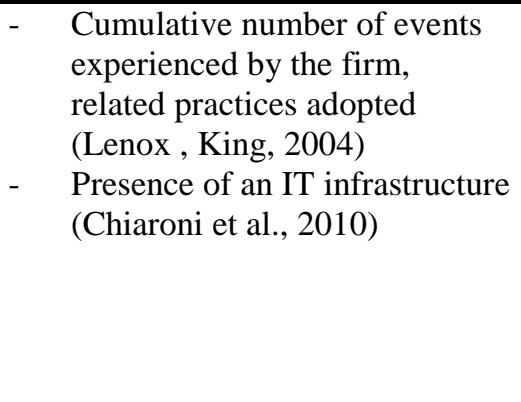 \\
\hline \multirow[t]{5}{*}{$\begin{array}{l}\text { ASSIMILATE } \\
\text { The firm's ability to analyse, } \\
\text { interpret, understand, share } \\
\text { and integrate valuable new } \\
\text { knowledge }\end{array}$} & - & $\begin{array}{l}\text { Competent } \\
\text { specialists }\end{array}$ & 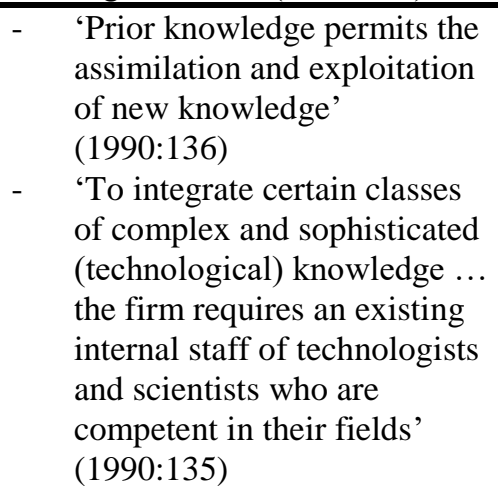 & 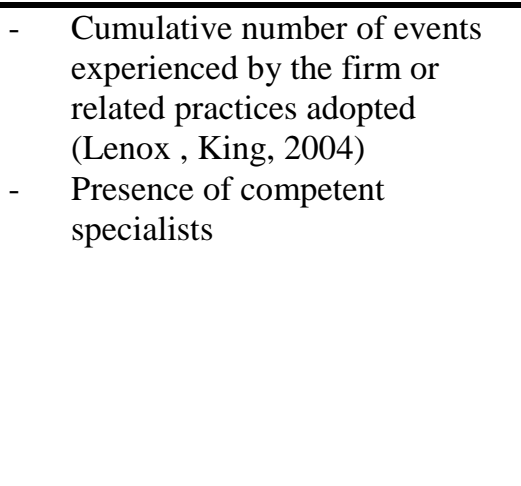 \\
\hline & - & Organic structure & $\begin{array}{l}\text { - } \quad \text { The organic structure of } \\
\text { Burn and Stalker (1961) is } \\
\text { more adaptable for ACAP' } \\
(1990: 132)\end{array}$ & $\begin{array}{l}\text { - Decentralization (Lane } \\
\text { Lubatkin, 1998) }\end{array}$ \\
\hline & - & $\begin{array}{l}\text { Staff with } \\
\text { various relevant } \\
\text { background } \\
\text { knowledge }\end{array}$ & $\begin{array}{l}\text { 'The staff should have a } \\
\text { relevant background } \\
\text { knowledge' (1990:132) }\end{array}$ & $\begin{array}{l}\text { - Education level of employees } \\
\text { (Escribano et al., 2009; } \\
\text { Kostopoulos et al., 2011) }\end{array}$ \\
\hline & - & R\&D activity & $\begin{array}{l}\text { - } R \& D \text { enhances the firm's } \\
\text { ability to assimilate and } \\
\text { exploit } \\
\text { information'(1989:21) }\end{array}$ & $\begin{array}{l}\text { Intensity of internal R\&D or } \\
\text { R\&D expenditures (Cohen } \\
\text { Levinthal, 1989, 1990) }\end{array}$ \\
\hline & - & $\begin{array}{l}\text { Communication } \\
\text { structures }\end{array}$ & $\begin{array}{l}\text { ACAP depends on 'transfers } \\
\text { of knowledge across and } \\
\text { within subunits ... on the } \\
\text { structure of communication } \\
\text { among the subunits of the } \\
\text { organization' (1990:132); }\end{array}$ & $\begin{array}{l}\text { - IT infrastructures (Chiaroni et } \\
\text { al., 2010); }\end{array}$ \\
\hline $\begin{array}{l}\text { APPLY } \\
\text { Commercial applications of } \\
\text { assimilated external } \\
\text { knowledge or firms' ability } \\
\text { to create something new } \\
\text { from assimilated knowledge }\end{array}$ & - & Prior knowledge & $\begin{array}{l}\text { 'Prior knowledge permits the } \\
\text { assimilation and exploitation } \\
\text { of new knowledge' } \\
\text { (1990:136) } \\
\text { 'R,D enhances the firm's } \\
\text { ability to assimilate and } \\
\text { exploit } \\
\text { information'(1989:21) }\end{array}$ & 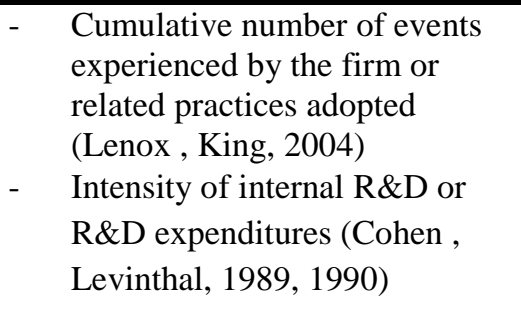 \\
\hline
\end{tabular}




\section{Appendix B.Absorptive capacity clusters}

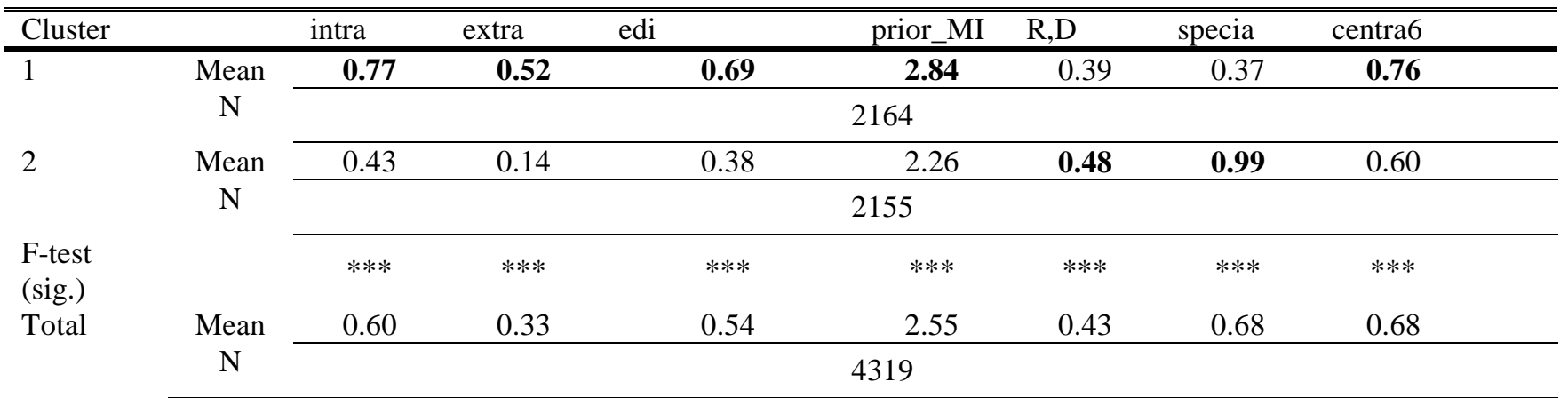

NOTES: We interpret Clusters 1 and 2 according to the variables in the cluster analysis. We computed the mean of each variable for each cluster. The mean appears in bold when it is significantly higher in the considered cluster. For example, the dimension VALUE (Cluster 1) use significantly more IT infrastructures among the organization (intra2006, extra2006, edi2006) and prior knowledge (sumopi03) than do Cluster 2 (ASSAP)

$* * *$ Significant at 0.01 . **Significant at 0.05 . *Significant at 0.10 .

\section{Appendix C. Means, standard deviations and correlation coefficients}

\begin{tabular}{|c|c|c|c|c|c|c|c|c|c|c|c|c|c|}
\hline & Mean & $\mathrm{SD}$ & (1) & (2) & (3) & (4) & (5) & (6) & (7) & (8) & (9) & $(10)$ & (11) \\
\hline 1. MI adoption intensity & 0.36 & 0.73 & 1 & & & & & & & & & & \\
\hline 2. Openness intensity & 1.84 & 1.47 & 0.17 & 1 & & & & & & & & & \\
\hline 3. Absorptive capacity & 0.38 & 0.49 & 0.11 & 0.30 & 1 & & & & & & & & \\
\hline 4. Client concentration & 0.38 & 0.49 & 0.03 & -0.08 & 0.08 & 1 & & & & & & & \\
\hline 5. Supplier concentration & 0.29 & 0.45 & -0.01 & -0.09 & 0.00 & 0.07 & 1 & & & & & & \\
\hline 6. Mimetic effects & 14.45 & 5.03 & 0.06 & 0.14 & 0.05 & 0.00 & -0.03 & 1 & & & & & \\
\hline $\begin{array}{l}\text { 7. Legitimation } \\
\text { motivation }\end{array}$ & 0.71 & 0.45 & 0.08 & 0.16 & 0.16 & 0.04 & -0.01 & 0.06 & 1 & & & & \\
\hline 8. Low tech industries. & 0.41 & 0.49 & 0.01 & -0.09 & -0.01 & -0.02 & 0.04 & -0.39 & -0.05 & 1 & & & \\
\hline 9. Firm size & 4.64 & 1.44 & 0.12 & 0.47 & 0.48 & 0.00 & -0.13 & 0.08 & 0.21 & -0.10 & 1 & & \\
\hline 10. Lack of resources & 0.11 & 031 & 0.10 & 0.08 & 0.06 & 0.00 & 0.00 & 0.02 & 0.05 & -0.04 & 0.09 & 1 & \\
\hline
\end{tabular}

